\title{
UPTAKE OF FREE AND COMPLEXED SILVER IONS BY DIFFERENT STRAINS OF RHODOTORULA MUCILAGINOSA
}

\author{
Newton C.M. Gomes ${ }^{1}$; Carlos A. Rosa²; Patrícia F. Pimentel³; Leda C.S. Mendonça-Hagler ${ }^{1 *}$ \\ ${ }^{1}$ Departamento de Microbiologia Geral, Instituto de Microbiologia, Universidade Federal do Rio de Janeiro, Rio de Janeiro, RJ, \\ Brasil. ${ }^{2}$ Departamento de Microbiologia, Instituto de Ciências Biológicas, Universidade Federal de Minas Gerais, \\ Belo Horizonte, MG, Brasil. ${ }^{3}$ Fundação Centro Tecnológico de Minas Gerais, Belo Horizonte, MG, Brasil
}

Submitted: April 30, 2001; Returned to authors for corrections: August 20, 2001; Approved: February 25, 2002

\begin{abstract}
Five strains of Rhodotorula mucilaginosa were tested for the ability to accumulate free and complexed silver ions by metabolism-dependent and -independent processes. The ability to take $\mathrm{up}^{\mathrm{Ag}^{+}}$was observed in both live and dead biomass, whereas silver dicyanide [Ag (CN)2-] uptake was strictly glucose dependent. In contrast to $\mathrm{Ag}(\mathrm{CN}) 2-$, glucose addition inhibited by 16 to $25 \%$ the $\mathrm{Ag}^{+}$uptake rate of living UFMG - Y02, Y27, and Y35 cells, while strains CBS 316 and UFMG-Y01 showed an improved uptake rate of about $115 \%$ and $13 \%$, respectively. The Langmuir sorption model was used to evaluate the silver sorption capability of the $R$. mucilaginosa strains. The calculated $\mathrm{q}_{\max }$ value suggested that $R$. mucilaginosa strains UFMG-Y27 had the highest loading capacity. The type strain CBS 316 had the lowest $\mathrm{q}_{\max }$ but showed the highest affinity for silver ions. The results provided by the Fourier Transform Infra Red analysis (FTIR) suggest that $\mathrm{C}=\mathrm{O}$ groups represent the main reactive site for silver uptake by the strain UFMG-Y27.
\end{abstract}

Key words: Bioaccumulation, biosorption, Rhodotorula mucilaginosa, silver

\section{INTRODUCTION}

Many metals and metalloids can be accumulated by yeasts and some of them are essential for structural and/or catalytic functions, whereas others are of no known metabolic importance (14). In general, microorganisms accumulate metals by biosorption or bioaccumulation processes. The first one involves metal adsorption around the cell envelope and is a metabolism-independent process. Bioaccumulation is strictly dependent on cell metabolism and involves active translocation of metals into the cell.

Biosorption phenomena occur as a result of metal ion interactions with functional groups in organic polymers on the cell surface (28). It is believed that phosphate, carboxyl, amine and amide groups found in carbohydrates, lipids, proteins, and other biopolymers of the microbial cell envelope represent the main sites for metal adsorption $(9,24,26)$. The charge distribution and geometry of these binding sites may vary with the composition of the cell envelope of each microorganism, resulting in markedly different metal-binding affinities.

Bioaccumulation is a much slower process of metal uptake than biosorption and may be inhibited by the absence of nutrients such as glucose, nitrogen, and phosphate, by low temperatures and by the action of metabolic inhibitors $(11,12,21)$. The process of metal accumulation and detoxification by living microorganisms includes metal sequestering by low molecular weight metabolic products (e.g. oxalic and citric acids), complexation and chelation of metals by sulfide and siderophores, enzymatically mediated metal deposition (e.g. phosphatase), influx of metals trough the cell membrane, metal binding by low molecular weight proteins (metallothioneins), and metal compartmentalization in vacuoles $(13,23,24)$.

\footnotetext{
* Corresponding author. Mailing address: Departamento de Microbiologia Geral, Instituto de Microbiologia Prof. Paulo de Góes, Bloco I, CCS, Universidade Federal do Rio de Janeiro, Ilha do Fundão. 21941-590, Rio de Janeiro, RJ, Brasil.
} 
Silver plating is extensively used by various industries for production of durable and decorative products. The metal is normally plated from alkaline cyanide solutions (4) that usually generate silver dicyanide $[\mathrm{Ag}(\mathrm{CN}) 2-]$ as a contaminant in the wastewater. Silver dicyanide may be accompanied by other silver species and is a chemically stable and extremely toxic metal complex of high mobility in the environment. Recently we have studied 56 yeast strains isolated during the cyanidation process for gold extraction. Rhodotorula mucilaginosa (Syn. Rhodotorula rubra) strain UFMG-Y27 was able to survive at concentrations of $\mathrm{Ag}(\mathrm{CN}) 2-$ up to $40 \mathrm{mg} \mathrm{l}^{-1}$, and had the highest ability to take up this compound compared to all other yeasts tested (15). By the light of interesting results obtained in our previous work we have attempted to study four $R$. mucilaginosa strains previously isolated (15) and the type strain (CBS 316). They were characterized taxonomically and investigated for their ability to remove free $\left(\mathrm{Ag}^{+}\right)$and complexed [Ag (CN)2-] silver ions from dilute aqueous solutions by metabolism-dependent and -independent processes.

\section{MATERIALS AND METHODS}

\section{Yeast source and identification}

Samples $(25 \mathrm{ml})$ were inoculated into flasks containing $25 \mathrm{ml}$ of two-fold concentrated yeast nitrogen base (YNB - Difco) supplemented with $1 \%$ glucose and $0.01 \%$ chloramphenicol or into $25 \mathrm{ml}$ of two- fold concentrated modified YGP broth medium containing final concentrations of $0.5 \%$ yeast extract, $1 \%$ peptone, $2 \%$ glucose and $0.01 \%$ chloramphenicol. The flasks were incubated at room temperature $\left(25 \pm 3^{\circ} \mathrm{C}\right)$ with shaking (250 rev/min) for 3-10 days. Pure cultures were obtained by streaking the yeast growth on YM agar $(0.3 \%$ yeast extract, $0.3 \%$ malt extract, $0.5 \%$ peptone, $1 \%$ glucose, and $2 \%$ agar). The yeasts were identified according to Barnett et al. (3) and Kurtzman and Fell (20).

Yeast biomass preparation for experiments on metabolismdependent and independent silver uptake

R. mucilaginosa strains were inoculated into Erlenmeyer flasks containing Yeast Carbon Base (YCB - Difco) supplemented with $0.1 \%\left(\mathrm{NH}_{4}\right)_{2} \mathrm{SO}_{4}$. Cells from the late exponential growth phase $(48 \mathrm{~h})$ were harvested by centrifugation at $1,200 \times \mathrm{g}$ for $10 \mathrm{~min}$ and washed three times with distilled deionized water. The fresh cell pellets $\left(1 \mathrm{mg} \mathrm{ml}^{-1}\right.$ dry weight) were immediately used for the metabolismdependent experiments and the remaining ones were dried at $60^{\circ} \mathrm{C}$ to a constant weight for the metabolism-independent experiments. Due to the high ability of chloride ions to form insoluble complexes with silver $(\mathrm{AgCl})$, all experiments were done in chloride-free medium to prevent precipitation of $\mathrm{Ag}^{+}$ as silver chloride.

\section{Metabolism-dependent silver uptake}

Living cells were added to $250 \mathrm{ml}$ Erlenmeyers flasks containing $25 \mathrm{ml}$ of $10 \mathrm{mM}$ morpholineethanesulfonic acid (MES) buffer, previously adjusted to $\mathrm{pH} 6.5$ with $1 \mathrm{M} \mathrm{NaOH}$ or $\mathrm{HNO} 3$ and $2 \%$ glucose (2). The final biomass concentration was $1 \mathrm{mg}$ (dry weight) $\mathrm{ml}-1$. Cell suspensions were previously equilibrated in MES buffer with glucose at $25^{\circ} \mathrm{C}$, with shaking $(250 \mathrm{rev} / \mathrm{min})$ for $1 \mathrm{~h}$ before the addition of $20 \mathrm{mg} \mathrm{l}^{-1}$ of silver as $\mathrm{Ag}(\mathrm{CN})_{2}^{-}$or $\mathrm{Ag}^{+}$using their respective salts $\mathrm{KAg}(\mathrm{CN})_{2}$ and $\mathrm{Ag} \mathrm{NO}_{3}$. After 12 hours of incubation the solution was centrifuged at $1,200 \times \mathrm{g}$ for $10 \mathrm{~min}$ and the supernatants were retained for metal analysis. Silver uptake values were determined from the difference between the final silver concentrations in the control flasks without yeast cells and in the test flasks. MES buffer was used because of its low metal-binding property $(2,16)$.

\section{Metabolism-independent silver uptake}

Dried yeast biomass was added to $25 \mathrm{ml}$ of $10 \mathrm{mM}$ MES buffer, $\mathrm{pH} 6.5$, to a final concentration of $1 \mathrm{mg}$ (dry weight) $\mathrm{ml}-1$ in $250 \mathrm{ml}$ Erlenmeyer flasks (2). Free and complexed silver ions, $\mathrm{Ag}+$ and $\mathrm{Ag}(\mathrm{CN}) 2-$, respectively, were added to the suspensions to the desired final concentrations ( 1 to $65 \mathrm{mg} \mathrm{l}^{-1}$ ). The flasks were incubated for $3 \mathrm{~h}$ and after this period the biomass was centrifuged at $1,200 \mathrm{x} g$ for $10 \mathrm{~min}$ and the supernatant was retained for silver analysis. The amount of metal removed was determined by the difference in metal content between flasks containing no biomass (control) and flasks containing biomass (test). Before each metabolism-independent experiment the dehydrated yeast biomass was rehydrated by pre-incubation in $10 \mathrm{mM}$ MES buffer (8 hours), pH 6.5, with magnetic stirring.

\section{Isotherm model}

The extent of experimental silver uptake by yeast biomass was expressed according to the following equation:

$$
\text { Metal uptake } \mathrm{q}=(\mathrm{Ci}-\mathrm{Cf}) \text {. V/M }
$$

Where $\mathrm{Ci}$ and $\mathrm{Cf}$ are the initial and equilibrium (final) metal ion concentrations $(\mathrm{mg} / \mathrm{L})$, respectively, $\mathrm{V}$ is the volume of sample solution (L), and $\mathrm{M}$ is the dry weight of the biomass added (g). In general, metabolism-independent metal uptake is directly related to metal sorption by the cell surface. The sorption data were fitted to the Langmuir adsorption isotherm model:

$$
\mathrm{q}=\left(\mathrm{b} \cdot \mathrm{Cf} \cdot \mathrm{q}_{\max }\right) /(1+\mathrm{b} \cdot \mathrm{Cf})
$$

Where $\mathrm{q}_{\max }$ is the maximum sorbate (metal) uptake and $\mathrm{b}$ is the Langmuir constant related to adsorption energy and it is an indication of the "apparent affinity" of the biosorbent toward the metal (28).

\section{Metal analysis}

Metal analysis was performed using an atomic absorption spectrophotometer with an air-acetylene flame (Varian model AA-475) by reference to appropriate standard metal solutions according to APHA (1). 


\section{Fourier- transform infrared (FTIR) analysis}

A FTIR spectrometer was used for the determination of the functional groups which may be involved in the silver biosorption process (10). Infrared spectra of silver-loaded and -unloaded yeast biomasses were recorded on a Perkin Elmer FTIR spectrometer (Model PARAGON 1000 PC). Disks of 100$\mathrm{mg} \mathrm{KBr}$ containing $1 \%$ of finely ground powder $(<20 \mathrm{~mm})$ of each sample were prepared less than 24 hours before recording.

\section{RESULTS AND DISCUSSION}

Although all R. mucilaginosa strains studied in this work had generally similar physiological profiles and were identified as members of that species, their carbon assimilation patterns presented discernible differences. The strains differed in their assimilation of trehalose, maltose, melezitose, L-arabinose, Dglucitol, ribitol, and manitol (Table 1). As with the taxonomic physiological tests, the silver uptake studies also showed a wide variation in metal uptake ability among all strains studied.

Nonliving (dried biomass) R. mucilaginosa strains UFMGY01, 02, 27, 35 and the type strain (CBS 316), were tested for the ability to accumulate free $\left(\mathrm{Ag}^{+}\right)$and complexed $[\mathrm{Ag}(\mathrm{CN}) 2-]$ silver ions. In all cases silver as $\mathrm{Ag}(\mathrm{CN}) 2$ - was refractory to the process of metabolism-independent metal uptake (biosorption, data not shown), whereas free silver ions were readily sequestered by the inactive biomass. The failure to take up silver as $\mathrm{Ag}(\mathrm{CN}) 2$ - may be attributed to the strength of the metal-anion complex or to repulsion of the negatively charged microbial cell surface for anionic metal complexes such as $\mathrm{Ag}(\mathrm{CN}) 2-$.

For comparative purpose, silver $\left(\mathrm{Ag}^{+}\right)$sorption data were quantitatively evaluated by adsorption isotherms and using the Langmuir model. Fitting the experimental adsorption data with the model was important in order to determine maximum metal uptake and to establish the affinity of the reactive sites on the cell surface for silver. The calculated $\mathrm{q}_{\max }$ (maximum metal

Table 1. Differences in the carbon assimilation patterns among the Rhodotorula mucilaginosa strains used in this study.

\begin{tabular}{lccccc}
\hline \multirow{2}{*}{$\begin{array}{c}\text { Carbon } \\
\text { source }\end{array}$} & \multicolumn{5}{c}{ Rhodotorula mucilaginosa strains } \\
\cline { 2 - 6 } & CBS- & UFMG- & UFMG- & UFMG- UFMG- \\
& $316^{\mathrm{T}}$ & Y01 & Y02 & Y27 & Y35 \\
\hline Trehalose & + & + & + & + & - \\
Maltose & + & + & + & $\mathrm{W}$ & $\mathrm{W}$ \\
Melezitose & + & + & + & - & + \\
L-arabinose & - & $\mathrm{W}$ & $\mathrm{W}$ & + & + \\
D-Glucitol & $\mathrm{W}$ & - & + & - & - \\
Ribitol & - & + & + & + & - \\
Manitol & - & $\mathrm{W}$ & + & - & - \\
\hline
\end{tabular}

${ }^{a}$ A positive or negative sign means ability or inability, respectively, to use the compound as a sole carbon source. $\mathrm{W}=$ weak ability to use the carbon source. ${ }^{\mathrm{T}}$ Type strain of $R$. mucilaginosa. accumulated) and b values (affinity) suggested that $R$. mucilaginosa strain UFMG-Y27 had the highest loading capacity, but not the highest affinity for silver (Table 2). The type strain CBS 316 had the lowest $\mathrm{q}_{\max }$ but showed the highest affinity for silver ions, as evidenced by the Langmuir parameter $\mathrm{b}$ (6.85). This high affinity to silver is of fundamental importance for removal of very dilute silver cations from wastewaters (17). The low $\mathrm{q}_{\max }$ and the high $\mathrm{b}$ value for silver shown by this strain would be explained by a relatively low number of sites for silver interaction on the cell surface, but with a very high reactivity of these binding sites for silver cations.

The infrared (IR) spectra of silver-loaded and -unloaded yeast biomass from the yeast strains were compared for the determination of functional groups which may be involved in the silver biosorption process $(8,10)$. With exception of UFMG - Y27, the IR spectra of the silver-loaded of $R$. mucilaginosa strains did not show significant differences in comparison a typical silverunloaded biomass. The $R$. mucilaginosa (UFMG - Y27) strain clearly displayed shifts of the stretching band located at 1650 $\mathrm{cm}^{-1}$ (Fig. 1). The stretching band at 1650 corresponds to amide I band - a CO stretching mode conjugated to $\mathrm{NH}$ deformation mode (18). The shifts of this band may correspond to the complexing of the carbonyl group by dative coordination to metals.

Fig. 2 represents the maximum uptake of free and cyanidecomplexed silver ions in the presence and absence of glucose. The maximum silver uptakes by dead yeasts are shown for comparison. The addition of glucose was important to evaluate the effect of an energy source during the process of silver uptake by a living yeast biomass. Both silver species $\mathrm{Ag}^{+}$and $\mathrm{Ag}$ (CN)2-) were taken up by the living yeasts in presence of glucose (Fig. 2). Curiously, strain CBS 316 had the maximum uptake of $\mathrm{Ag}(\mathrm{CN}) 2$ - in presence of glucose. However, $\mathrm{Ag}(\mathrm{CN}) 2$ - uptake by the living yeast strains was not detectable in the absence of glucose (data not shown), clearly showing that glucose is of fundamental importance for $\mathrm{Ag}(\mathrm{CN}) 2$ - uptake.

The glucose dependence of $\operatorname{Ag}(\mathrm{CN}) 2$ - uptake is a strong indication that the uptake of this compound is an energy-

Table 2. Biosorption parameters for silver uptake resulting from equilibrium uptake studies of five strains of Rhodotorula mucilaginosa.

\begin{tabular}{lrc}
\hline \multicolumn{1}{c}{ Strain number } & \multicolumn{1}{c}{$\mathrm{q}_{\max }$} & $\mathrm{b}$ \\
\hline CBS 316 $^{\mathrm{T}}$ & $3.41 \pm 0.28$ & $6.85 \pm 2.58$ \\
UFMG-Y01 & $19.20 \pm 0.36$ & $0.32 \pm 0.02$ \\
UFMG-Y02 & $10.06 \pm 0.14$ & $0.98 \pm 0.08$ \\
UFMG-Y 27 & $22.20 \pm 0.32$ & $0.74 \pm 0.05$ \\
UFMG-Y35 & $15.89 \pm 0.46$ & $0.59 \pm 0.07$ \\
\hline
\end{tabular}

$\mathrm{q}_{\max }$ - the maximum metal accumulated reported as mg metal g ${ }^{-1}$; b - Langmuir constant related to adsorption energy; $\mathrm{T}$ - Type strain of $R$. mucilaginosa. 


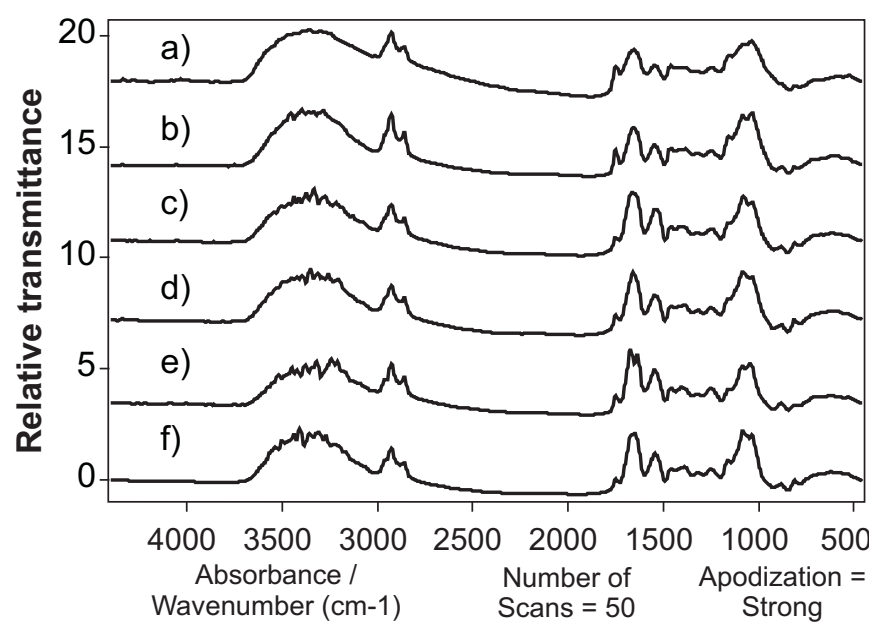

Figure 1. Infrared spectra (3000-400) of a typical silverunloaded biomass (a- type strain) and silver loaded biomass ( $b=$ CBS316, $c=$ UFMG-Y01, d= UFMG-Y02, e= UFMG-Y27 and $\mathrm{f}=\mathrm{UFMG}-\mathrm{Y} 35$ ).

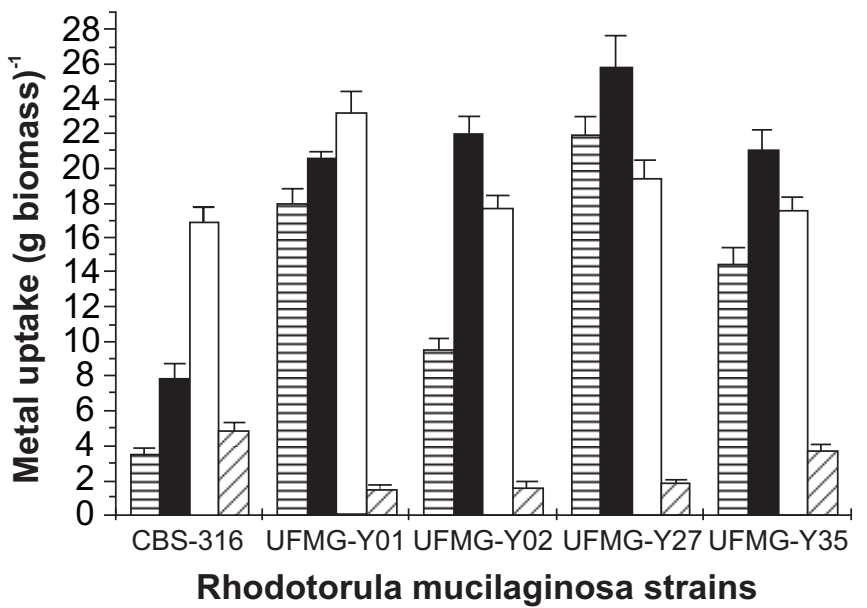

Figure 2. Comparison of maximum uptake of free silver ions $\left(\mathrm{Ag}^{+}\right)$by nonliving (目) and live cells of $R$. mucilaginosa in the absence ( $\square$ ) and the presence ( $\square$ ) of $2 \%$ glucose (w/v). The maximum active uptake of complexed silver ions $[\mathrm{Ag}(\mathrm{CN}) 2-]$ in the presence of glucose is also shown ( $\triangle)$. The biomass concentration was $1 \mathrm{mg} \mathrm{ml}^{-1}$ (dry weight), and the initial silver concentration was $20 \mathrm{mg} \mathrm{l}^{-1}$ for both $\mathrm{Ag}^{+}$and $\mathrm{Ag}(\mathrm{CN}) 2-$. Each column represents the mean of three independent experiments; the bars correspond to the standard deviations.

dependent process. All strains had a higher ability to accumulate free silver ions when metabolically active. Since living cells can present all types of non-metabolic interactions with metals as well as interactions that require active metabolism, we may assume that yeasts may accumulate more metals when they are metabolically active than when they are inactive. Glucose addition also had influence on free silver ions $\left(\mathrm{Ag}^{+}\right)$uptake by the yeasts. Strains UFMG-Y02, Y27, and Y35 showed a reduction in uptake rate of about $19 \%, 25 \%$ and $16 \%$, respectively, when glucose was added, whereas strains CBS 316 and UFMG-Y01 showed an increased uptake rate about $115.1 \%$ and $12.7 \%$, respectively. Several investigators explain the increase in metal uptake caused by glucose as the result of an improvement of the mechanisms of membrane transport (e.g., an increased synthesis of transport proteins) (2,5). Although strains UFMG-Y01 and CBS 316 exhibited such an improvement, the decrease in $\mathrm{Ag}^{+}$uptake observed for the other three strains in the presence of glucose is not in agreement with the transport model. Therefore, we can assume that, in some cases, the addition of glucose to the metal solution can be prejudicial for the evaluation of microorganisms potentially important for metal removal.

In general, glucose causes microorganisms to pump out $\mathrm{H}^{+}$ ions and transport them into the cell via a symport mechanism. These $\mathrm{H}^{+}$ions are frequently bound to anionic sites on the cell wall, resulting in competition between protons and metal cations for anionic sites on the microbial cell $(6,27)$. In agreement with the results shown previously for $\mathrm{Ag}(\mathrm{CN}) 2-$ uptake, it is reasonable to assume that this phenomenum could be useful to increase adsorption of anionic charged metal complexes to the cell surface.

Since the potential of $R$. mucilaginosa and other species of this genus has been evaluated for removal of heavy metals from solutions $(7,19,22,25)$, it is important to stress that $R$. mucilaginosa strains can show many phenotypic differences. In this work we observed that $R$. mucilaginosa strains have physiological differences and they also show considerable variation in metal removal capacity.

Due the complexity of the industrial wastewater environment, silver can be found under different chemical forms. Therefore, the evaluation of microorganisms able to uptake silver in its complex forms is of fundamental importance to develop feasible bioprocesses to remove or recover silver from industrial waste waters. Both live and dead cells of $R$. mucilaginosa strains were able to take up $\mathrm{Ag}^{+}$, whereas silver dicyanide [ $\left.\mathrm{Ag}(\mathrm{CN}) 2-\right]$ uptake was a strictly energy- dependent process. The strain UFMG - Y27 can resist to high concentrations of $\mathrm{Ag}(\mathrm{CN}) 2$ (15), and since metal cyanide complex uptake seems to be mostly an energy- dependent process, this characteristic is of fundamental importance for silver dicyanide removal by it from industrial effluents.

\section{ACKNOWLEDGMENTS}

We acknowledge funding by the Conselho Nacional de Desenvolvimento Científico e Tecnológico (CNPq), the Fundação de Amparo e Pesquisa do Estado de Minas Gerais (FAPEMIG) and PADCT (grant 430/95). We thank Dr. Allen N. Hagler for providing the Rhodotorula mucilaginosa type strain. 


\section{RESUMO}

\section{Acúmulo de íons de prata livres e complexados por diferentes linhagens de Rhodotorula mucilaginosa}

Quatro linhagens de Rhodotorula mucilaginosa e uma linhagem padrão dessa mesma espécie foram investigadas quanto a habilidade de acumular íons de prata livres $\left(\mathrm{Ag}^{+}\right)$e complexados [Ag (CN)2-], através de processos dependentes e independentes do metabolismo. A habilidade de acumular $\mathrm{Ag}^{+}$ foi observada em ambas as células, vivas e mortas. Contudo, o acúmulo de $\mathrm{Ag}(\mathrm{CN}) 2$ - foi um processo estritamente dependente de energia. Durante os estudos que avaliaram a dependência de uma fonte energética para o acumulo de íons de prata livres $(\mathrm{Ag}+)$ foi observado que a adição de glicose resultou na diminuição do acúmulo de Ag+ por três linhagens (UFMG Y02, 27 and 35). Ao passo que as linhagens CBS 316 e UFMG Y01 apresentaram aumento do acúmulo desse metal. A analise dos resultados de biossorção através do modelo de Langmuir, sugerem que a linhagem UFMG - Y27 possui a maior capacidade de acúmulo de prata (carga). Enquanto que a linhagem padrão CBS 316 apresentou a menor capacidade de carga e a maior afinidade por ions de prata. Analises de infra vermelho da biomassa fúngica, com e sem prata, mostraram que os grupamentos $\mathrm{C}=\mathrm{O}$ foram os principais sítios de ligação desse metal pela linhagem UFMG - Y27.

Palavras-chave: bioacumulação, biossorção, Rhodotorula mucilaginosa, prata

\section{REFERENCES}

1. Greenberg, A.E.; Clesceri, L.S.; Eaton, A.D. Standard Methods for the Examination of Water and Wastewater 18th. ed. APHA, Washington, 1992.

2. Avery, S.V.; Tobin, J.M. Mechanisms of strontium uptake by laboratory and brewing strains of Saccharomyces cerevisiae. Appl. Environ. Microbiol., 58: 3883-3889, 1992.

3. Barnett, J.A.; Payne, R.W.; Yarrow, D. Yeasts: Characteristics and identification, Cambridge, Cambridge University Press, 1990.

4. Blair, A. Silver plating. Plat. \& Surf. Finishing., 82: 70-71, 1995.

5. Cervantes, C.; Gutierrez-Corona, F. Cooper resistance mechanisms in bacteria and fungi. FEMS Microbiol. Rev., 14: 121-138, 1994.

6. Doyle, R.J. How cell walls of gram-positive bacteria interact with metal ions. In: Beveridge, T.J.; Doyle, R.J. (eds). Metal ions and bacteria. John Wiley \& Sons, Inc. New York, 1989, p.275-294.

7. Falih, A.M. Comparative toxicity of heavy metals to some yeasts isolated from Saudi Arabian soil. Bioresource Technol., 64: 193$198,1998$.
8. Figueira, M.M.; Volesky, B.; Mathieu, H.J. Instrumental analysis study of iron species biosorption by Sargassum biomass. Environ. Sci. Technol., 33: 1840-1846, 1999.

9. Fourest, E.; Roux, J.C. Heavy metal biosorption by fungal mycelial by-products: mechanisms and influence of $\mathrm{pH}$. Appl. Microbiol. Biot., 37: 399-403, 1992.

10. Fourest, E.; Volesky, B. Contribution of sulphonate groups and alginate to heavy metal biosorption by the dry biomass of Sargassum fluitans. Environ. Sci. Technol., 30: 277-282, 1996.

11. Fuhrmann, G.F.; Rothstein, A. The transport of $\mathrm{Zn}^{2+}, \mathrm{Co}^{2+}$ and $\mathrm{Ni}^{2+}$ into yeast cells. Biochim. Biophys. Acta, 163: 325-330, 1968.

12. Gadd, G.M. Fungal responses towards heavy metals. In: Herbert, R.A.; Codd, G.A. (eds). Microbes in Extreme Environments. Academic Press, London, 1986, p.83-110.

13. Gadd, G.M.; White, C. Microbial tratment of metal pollution - a working biotechnology. TIBTECH., 11: 353-359, 1993.

14. Gomes, N.C.M.; Mendonça-Hagler, L.C.S.; Savvaidis, I. Metal bioremediation by microorganisms. Mini review. Rev. Microbiol., 29: 85-92, 1998.

15. Gomes, N.C.M.; Rosa, C.A.; Pimentel, P.F.; Linardi, V.R.; MendonçaHagler, L.C.S. Uptake of free and complexed silver ions by yeasts isolated from a gold mining industry in Brazil. J. Gen. Appl. Microbiol., 45: 121-124, 1999.

16. Good, N.E.; Winget, G.D.; Winter, W.; Connolly, T.N.; Izawa, S.; Singh, R.M.M. Hydrogen ion buffers for biological research. Biochemistry., 5: 467-474, 1966.

17. Kapoor, A.; Viraghavan, T. Fungal biosorption - an alternative treatment option for heavy metal bearing wastewaters: a review. Biores. Technol., 53: 359-371, 1995.

18. Kapoor, A.; Viraraghavan, T. Heavy metal biosorption sites in Aspergillus niger. Biores. Technol., 61: 221-227, 1997.

19. Kurek, E.; Czaban, J.; Bollag, J.M. Sorption of cadmium by microorganisms in competition with other soil constituintes. Appl. Environ. Microbiol., 43: 1011-1015, 1982.

20. Kurtzman, C.P.; Fell, J.W. The Yeasts: a Taxonomic Study $4^{\text {th }}$ ed., Elsevier Science Publischers B.V., Amsterdam, 1998.

21. Mowl, J.L.; Gadd, G.M. Zinc uptake and toxicity in the yeasts Sporobolomyces roseus and Saccharomyces cerevisiae. J. Gen. Microbiol., 129: 3421-3425, 1983.

22. Norris, P.R.; Kelly, D.P. Accumulation of metals by bacteria and yeasts. Dev. Ind. Microbiol., 20: 299-308, 1979.

23. Premuzic, E.T.; Lin, M.; Zhu, H.L.; Gremme, A.M. Selectivity in metal uptake by stationary phase microbial populations. Arch. Environ. Contam. Toxicol., 20: 234-240, 1991.

24. Remacle, J. The cell wall and metal binding. In: Volesky B. (ed). Biosorption of Heavy Metals. CRC Press, Boca Raton, 1990, p.83-92.

25. Salinas, E.; de Orellano, M.E.; Rezza, I.; Martinez, L.; Marchesvky, E.; de Tosetti, MS. Removal of cadmium and lead from dilute aqueous solutions by Rhodotorula rubra. Bioresource Technol., 72: 107-112, 2000.

26. Sonnenfeld, E.M.; Beveridge, T.J.; Koch, A.L.; Doyle, R.J. Asymmetric distribution of charge on the cell wall of Bacillus subtilis. J. Bacteriol., 163: 1167-1171, 1985.

27. Urrutia-Mera, M.; Kemper, M.; Doyle, R.; Beveridge, T.J. The membrane-induced proton motive force influences the metal binding ability of Bacillus subtilis cell walls. Appl. Environ. Microbiol., 58: 3837-3844, 1992.

28. Volesky, B. Removal and recovery of heavy metals by biosorption. In: Volesky B. (ed). Biosorption of Heavy Metals., CRC Press, Boca Raton, 1990, p.7-43. 